\title{
DISASTER MITIGATION BASED ON COMMUNITY INSTITUTIONS IN DISASTER- PRONE AREAS IN GARUT DISTRICT INDONESIA
}

\author{
Rd. Ahmad Buchari \\ Faculty of Social and Political Sciences, Universitas Padjadjaran, Jl. Raya Bandung-Sumedang KM. 21 \\ E-mail: ahmad.buchari@unpad.ac.id
}

\begin{abstract}
Demographically, Garut District is vulnerable to the occurrence of natural disasters due to the predominantly mountainous region. Disaster mitigation is the first step of prevention. Disaster mitigation conducted in Garut District was forming a disaster response village by using three aspects namely planning, institutional-level village and strengthening the community capacity as an effort to build a community resistance and responsive to the disaster. Institutional established in the village is useful to organize citizens to improve the awareness and social sense. While capacity building is a form of village, training resources to become volunteers whose focus is on entrepreneurship and disaster. The purpose of this research is to discover how disaster mitigation is based on community institutions in disaster-prone areas in Garut Regency. This study uses a qualitative approach by conducting sampling in three Disaster-resilient Villages, namely Pasawahan, Rancabango, and Karyamekar. This research uses observations, interviews and literature studies with analysis tools to see the village's institutional in conducting disaster mitigation management with such aspects: 1) planning; 2) institutional; and 3 ) capacity building. The results show that disaster response training is not delivered optimally to citizens, and is still limited to volunteers established in each RT/RW. Therefore, the village government should increase the participation of citizens through training in all groups by planning and maximizing the disaster-resilient village with the institutional and capacity development both disaster volunteers and communities to reduce the loss of disaster and encourage villagers to conduct a green activity and maintain the environment to remain beautiful.
\end{abstract}

Key words: Management; Disaster Mitigation; Volunteer; Garut District and Community Institution

\section{MITIGASI BENCANA BERBASIS LEMBAGA MASYARAKAT DI KAWASAN RAWAN BENCANA DI KABUPATEN GARUT INDONESIA}

\begin{abstract}
ABSTRAK. Secara demografis, Kabupaten Garut rentan terhadap terjadinya bencana alam karena wilayahnya yang didominasi pegunungan. Mitigasi bencana merupakan langkah awal dalam mencegah bencana yang dihadap. Mitigasi bencana dilakukan di Kabupaten Garut yaitu dengan membentuk desa tanggap bencana dengan menggunakan tiga aspek perencanaan, kelembagaan tingkat desa dan penguatan kapasitas masyarakat sebagai upaya membangun masyarakat yang tahan dan tanggap terhadap bencana. Kelembagaan yang dibentuk di desa berguna untuk menata warga lebih lanjut guna meningkatkan kesadaran dan rasa sosial yang tinggi. Sedangkan capacity building merupakan bentuk desa, melatih sumber daya menjadi relawan yang bergerak dan fokus pada tugas kewirausahaan dan kebencanaan. Tujuan dari penelitian ini yaitu untuk mengetahui bagaimana mitigasi bencana berbasis lembaga masyarakat pada kawasan rawan bencana di Kabupaten Garut. Penelitian ini menggunakan pendekatan kualitatif dengan melakukan pengambilan sampel di tiga berstatus Desa Tangguh Bencana, yaitu Pasawahan, Rancabango dan Karyamekar. Penelitian ini menggunakan observasi, wawancara dan studi pustaka dengan alat analisis untuk melihat kelembagaan desa dalam melakukan penanggulangan bencana dengan tiga aspek yaitu 1) perencanaan; 2) kelembagaan; dan 3) peningkatan kapasitas. Hasil ini menunjukkan bahwa pelatihan tanggap bencana belum maksimal diberikan kepada seluruh warga, dan masih terbatas pada relawan yang dibentuk di masing-masing RT / RW. Maka dari itu, pemerintah desa harus meningkatkan partisipasi warga melalui pelatihan di semua kelompok melalui perencanaan dan maksimalisasi desa tahan bencana dengan pengembangan kelembagaan dan kapasitas baik dari relawan bencana maupun masyarakat untuk mengurangi risiko kerugian bencana dan mendorong warga desa untuk melakukan aktivitas penghijauan dan menjaga lingkungan agar tetap asri.
\end{abstract}

Kata kunci: Manajemen; Mitigasi Bencana; Relawan; Kabupaten Garut dan Lembaga Masyarakat

\section{INTRODUCTION}

Disaster is a phenomenon that is often discovered in Indonesia, it is not uncommon for disasters to bring suffering and loss of material. Indonesian community are already able to understand the characteristics of disasters that will occur, long before the advanced technology develops like the era of contemporary, although indeed in reality technology can help minimize the losses caused from Even natural disasters are not always working as expected.
Referring to (Pemerintah Republik Indonesia, 2007) about disaster relief that was explained that the unitary State of Indonesia Republic has a geographical, biological, hydrological, and demographic condition that allows disaster. Whether caused by natural factors, non-natural factors, as well as human factors that cause the occurrence of human casualties, environmental damage, property loss, and psychological impacts under certain circumstances can impede national development. Emergency response is required which is a series of activities 
undertaken immediately in a disaster condition to deal with the adverse effects, including rescue activities and evacuation of victims, property, fulfillment Basic necessity, protection, refugee management, rescue, as well as restoration of infrastructure and facilities.

The mitigation is done to reduce the risk caused by the disaster. In the disaster management cycle, mitigation becomes part of the pre-disaster stage (Pancasilawan, et. al., 2020). Disaster mitigation Management in Indonesia is then governed by Presidential Regulation No. 8 in 2008 about national Disaster Management Agency, Government Regulation(PP)No. 21 in 2008 about implementation of disaster management, regulation Minister of Home Affairs No. 46 in 2008 about organizational guidelines and the working procedure of regional disaster management Agency. In addition, there is also regulation of the head of National Disaster Management Agency No. 3 in 2008 about guidelines on forming the Regional Disaster Management Agency, as well as regulation of the head of National Disaster Management Agency No. 11 in 2008 about Post-disaster rehabilitation and reconstruction guidelines. These arrangements related to Disasterregulatory.

The institution entitled to have authority over responsibility for disaster mitigation is the National Disaster Management Agency known as (BNPB), as a non-ministerial government institution that has the task of formulating and establishing a disaster mitigation policy. On a high level, the institute is located at the Provincial and Regency/City and has the task of providing guidance and direction to disaster management efforts that include disaster prevention, handling of emergency response, rehabilitation, and reconstruction in a fair and equal. Moreover, it also has the right to convey information on disaster management activities to the Community such as disaster response, training and community education and environmental activities.

The community needs to be involved in disaster mitigation efforts by BNPB for disaster prevention and community empowerment. The public role in disaster management was becoming a highlight in various world countries in Indonesia (Perry \& Lindell, 1997). There are several factors, including the development of the rules on disaster management impacts of local communities to have knowledge of disaster hazards and mitigation plans. As for the other things that pertain to how to share information and how to react to that information is then a matter of question for practitioners and researchers (Fisher, 1991; Otway \& von Winterfeldt, 1992). The public plays as an active role in the prevention and protection process, it concerns factors that motivate them to do so (Larsson \& Enander, 1997). And the public was already doing preparedness and can take better emergency measures when in crisis conditions (Weisæth, 1989), then raises concerns about how to increase engagement and improvement of ability Communities in order to reduce community vulnerabilities in disaster situations.

BNPB Institute has a strategy in developing a tough Village/Sub-District for Community-Based Disaster Risk Reduction known as (PRBBK). Selected villages will have the capacity and adaptive readiness to overcome the hazard and to recover from the impact of the disaster. In order to realize Integrity Disaster Village known as (Destana), all stakeholders, Village/Sub-District devices, the community must actively participate and must receive infrastructure, economic, political, and socio-cultural support. In addition, the community will have a communitybased early warning system, contingency planning, and evacuation pathways based on their knowledge of their environment. In addition, there should be an economic endurance pattern as a survival-supporting element when the disaster actually occurs at any time.

West Java province is one of the regions with a high level of insecurity in Indonesia. Its territory is dominated by hilly and mountain topography, located in the volcanic environment, and flanked by the Indian Ocean and Java Sea. Based on the measurement of Disaster Risk Index in Indonesia known as (IRBI) by National Disaster Management Agency known as (BNPB) there are seven common disaster risk in Java Island namely abrasion, flood, epidemic, earthquake, volcano, building fire and Settlements, forest fires and land, technological failures, droughts, social conflicts, landslides, tornado wind and Tsunami. Based on the Indonesian Disaster Prone Index (IRBI) released by the National Disaster Management Agency (BNPB) Indonesia on 14 December 2016 stated that West Java province is the province with the largest city of disaster priorities in Indonesia. With the number of incidents are reaching 3.300 catastrophic events and ranked second as the province has the most number of events Disasters in Indonesia in 2017 (DIBI, BNPB, 2017.)

District in West Java province, which includes a level of risk of natural disasters, is Garut District so that it is crowned as a miniature of Indonesian natural disasters. Based on data of Indonesian Disaster Prone Index (2011), Garut District is in the position of First as a district with high insecurity with a score of 139 at the national level, while Tasikmalaya District with a score of 133, which is lower. This is because Garut District area, which has an area of 306,519.00 
$\mathrm{km}$ from 42 sub-districts, is at an altitude of $717 \mathrm{~m}$ DPL that is surrounded by Karacak Mount (1.838 m), Cikuray Mount (2.821 m), Papandayan Mount (2.622 m), and Guntur Mount (2.249 m). Its northern topography characteristics consist of plateaus and mountains, while the southern part of the surface has a steep steepness rate and in some areas are unstable.

Some of the most frequent disasters plagued Garut District is drought and mudslide and forest fires. District Disaster Management Agency known as (BPBD) in Garut District recorded until April 2015 there are 42 events that include 29 incidents of landslides, 8 occurrences of wind and 5 flood incidents.

Based on the explanation above, the high level of natural disasters in Garut District issued by BPBD as a regional disaster management Agency should work optimally in conducting a disaster control that still considered weak. Institutional level of the village is strengthened by standby and response to disaster into social capital in order to conduct disaster mitigation management.

This research uses disaster management theory, the understanding of disaster management itself was a planned process that executed to manage the disaster well and securely through three phases (Ramli, 2010). First there is a pre-disaster stage consisting of preparedness, mitigation, and early warning, Second there is a time of disaster/emergency response, and Third is a post-disaster consisting of rehabilitation and reconstruction.

The pre-disaster phase starts from preparedness to anticipate disasters through organizing and through appropriate measures. Communities must be sensitive to the disaster and early estimate of the weather in the flood. Communities that settle in flood-prone areas to prepare for catastrophic possibilities. Early warning systems are necessary so that people can know the disaster and socialization of mechanisms when the disaster comes to prevent the worst impact.

The emergency response stage is the most crucial stage because it is a series of activities that are done immediately to prevent the worst impact. In emergency response, flood disaster is done by turning off the electricity that could cause fire or stung. Then create a comfortable and healthy emergency post to avoid disease and basic needs such as food, medicines, personal needs and others. The postdisaster phase occurs after the disaster period expires or the emergency status has been revoked. The steps are rehabilitation and reconstruction. Rehabilitation is the restoration of all aspects of society's life to an adequate level with the main target of normalizing daily activities. Then reconstruction is the rebuilding of facilities and infrastructure, institutional in postdisaster areas.

The Research on disaster mitigation that was conducted by (Harahap, 2016), by looking at external coordination function of BPBD institution in Tasikmalaya District. Coordination of BPBD district level with local governments in the mitigation of natural disasters in the form of interdisciplinary is the coordination in efforts to synchronize actions in order to create discipline among units that have a purpose both internally and externally. Meanwhile, interrelated coordination developed is coordination between institutions that function interdependent or have internal and external relationships.

The Other research conducted by Other research conducted by (Harliani, 2014) about the perception of community Cieunteung Village, Bandung Regency, concerning the plan for relocation post flood. The majority of public Village Cieunteung rejected the relocation plan that the government would do. The perception of planned relocation is related to several deciding factors, including physical and environmental aspects, economic aspects, community internal characteristics, socio-cultural aspects, information dissemination process, interstakeholder communication Interests, and community involvement in the decision-making process. (2014) on the perception of community Cieunteung Village, Bandung Regency, concerning the plan for relocation post flood. The majority of public Village Cieunteung rejected the relocation plan that the government would do. The perception of planned relocation is related to several deciding factors, including physical and environmental aspects, economic aspects, community internal characteristics, sociocultural aspects, information dissemination process, inter-stakeholder communication Interests, as well as community involvement in the decision-making process.

Increased public knowledge of disasters is considered by very important to be socialized so that catastrophic losses can be reduced. The local government of Blitar District of East Java Province is considered successful in improving the Kelud disaster mitigation system in the period of $1990-2014$. These victims are decreasing annually and system developmentand mechanisms are experiencing Better change and structure, technological developments and good handling from the government made the disaster victims of Kelud Mountain annually is less (Anam et al., 2016). Meanwhile, mitigation education should be entered into formal education in both an intra-curricular and extracurricular activities. Disasters and disaster response simulations should be 
a serious concern to the State, especially on policymaking to better govern the mechanisms of learning (Arifa, 2018).

\section{METHOD}

The methods section provides an explanation of the types of research / research designs. This section explains the number of subjects and the characteristics of the subject demographic data collection (Azwar, 2007). In quantitative research, if the research uses certain measuring instruments, it is necessary to convey the name of the measuring instrument, the number of items, the reliability coefficient, and the data analysis method used. In qualitative research, qualitative perspectives are used, and methods of data collection and analysis are discussed (Willig, 2008).

\section{RESULTS AND DISCUSSION}

Village or Sub-District Catastrophe Disaster has the ability to recognize threats in its territory and is able to organize Community resources to reduce vulnerability and increase capacity to reduce disaster risk. This capability is realized in development planning that contains prevention efforts, preparedness, disaster risk reduction and capacity building for post recovery. In DisasterResilient Villages known as Destana, communities are actively involved in reviewing, analyzing, addressing, monitoring, evaluating and mitigating catastrophic risks in their region, especially by utilizing local resources to ensure continuity.

Generally, the incidence of disaster in the district in a span of five years (2011-20150 classified into four terms, namely landslides, earthquakes, winds, floods and fires. Land fires dominated from the four incidents of the disaster and landslides accompanied by the wind and the flood that often occurred and befell the villagers around the region, which is potentially incident as shown in the following graph.

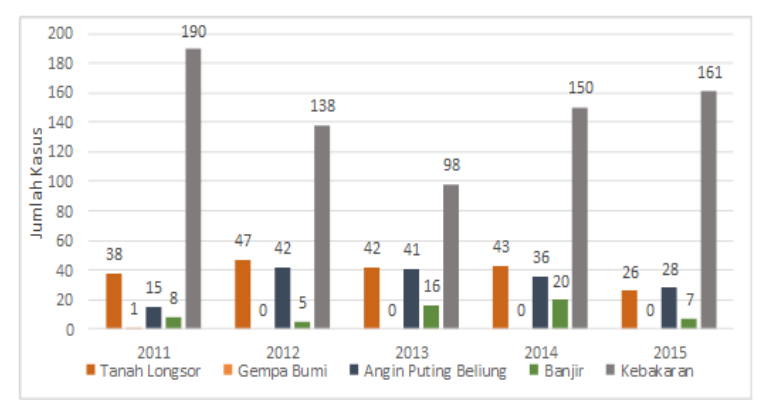

Source: Department of Social Labour and Transmigration of Garut District (2016)

Figure 1. Cases of Disaster Incident in Garut District During The Period 2011-2015
The amount of loss from the natural disaster as compiled by the National Disaster Management Agency (BNPB) in 2016 with a victim of 6,449 people while the destruction of houses and public facilities such as education, worship and Health Also affected. A total of 1,209 people's homes are affected by disasters and there is a degree of school education activities for teachers, students, and access to health so that they are felt by relief citizens and help from the local government. Loss Data as attached to the table below.

Table 1. Data on Disaster loss of Garut District in 2016

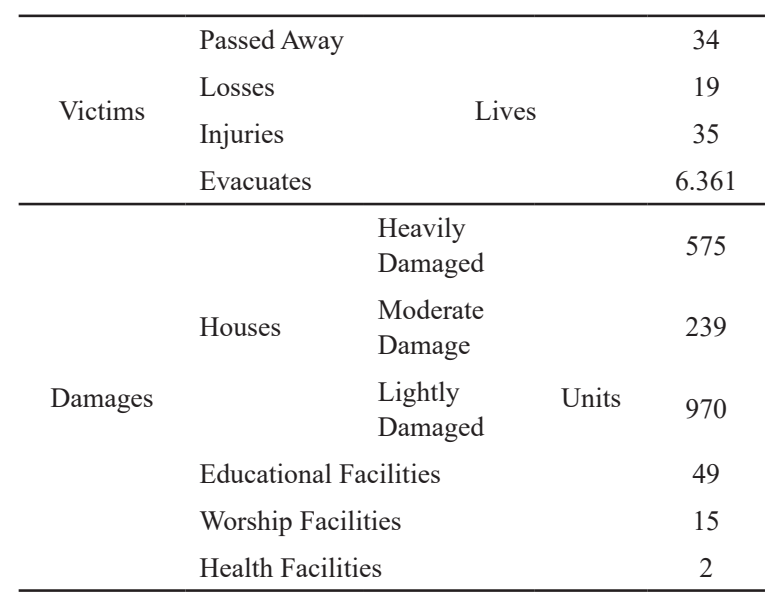

Source: National Disaster Management Agency (BNPB) in 2016

Disaster-Resilient Villages known as (Destana) in Garut District which is used as a research object, namely Pasawahan Village, Rancabango Village, and Karyamekar Village. The following are the reviews of the three villages as follows.

\section{Pasawahan Village}

Pasawahan village is one of 13 villages located in Tarogong Kaler Sub-district, of Garut District, West Java Province, which is a disaster prone to fire, especially Mountain Fire. Pasawahan village, which is located near the foot of Guntur Mount, which is the volcano, is still active with volcanic activity, the Thunder volcano also has a steep slope level with sandy and rocky soil material. For the stability of Guntur Mountain Land, this is categorized as unstable, with a high level of soil cladding and adequate soil absorption.

Communities in Pasawahan village have the ability to predict the occurrence of eruptions, among them identifying signs of the incident can be seen when all wild animals are coming down from the mountain, when the ambient temperature has increased. In addition, local wisdom in the preservation of the environment of local communities since ancient times local people preserve the preservation of Guntur Mount by planting trees when they want to climb 
up the mountain, other than that when it is about to drop They take the river line clearing the stream from garbage when it enters the rainy season.

Communities in Pasawahan Village located at the foot of Guntur Mount until today are still tied to the traditional belief that is called to sound the gamelan in the form of Goong. The word 'goong' itself is an ancient Sudanese term meaning gamelan. The local people still believe that when they do a feast or a feast, they are forbidden to ring this Goong, if it is violated then the inhabitants in Pasawahan village will experience a disaster.

The belief in the prohibition of sounding Goong until today is still firmly held by the people of the foothills of Guntur Mountain Village. In addition to these beliefs and activities, there are still some activities undertaken by the local community in the face of a disaster. Suppose that when the rainy season comes, usually to ward off flood disasters and wind rain, the surrounding community will do some sort of ritual praying together and giving offerings as a disaster relief effort.

\section{Rancabango Village}

Rancabango Village is a village with characteristics similar to Pasawahan Village, located close to Guntur Mount and categorized as disaster prone village. Rancabango Village is located in Tarogong Kaler Sub District. Referring to local village officials ' narrative, local wisdom related to disaster management in Rancabango Village had existed, as for what and how local wisdom developed said that it is difficult to trace the trail Its existence because of the mindset and the level of religiosity of local people has changed, this then affects the loss of local wisdom.

\section{Karyamekar Village}

Karyamekar Village is located in Cilawu Subdistrict is one of the disaster response villages. Public knowledge on disaster preventive measures, disaster evacuation and disaster relief has been fulfilled bless to the training conducted by BPBD (Regional disaster Management Agency). The community has carried out preventive measures to prevent landslides by planting trees that can withstand water in cliffs or slope areas that could potentially cause landslides.

Village Disaster Resilient is a national program formed in accordance with the head regulation of BNPB Number 01 in 2012 about the village guidelines/villages resilient disaster. The existence of this program in addition to realizing Indonesia resilient is also a manifestation of government responsibility for its people, especially in the case of disaster management. People are directly affected by the disaster and as well as the first perpetrator who will respond to the surrounding disaster.

Thus, the community needs to be equipped with the ability and capacity building to be empowered and resilient in facing the disaster. Some components in the disaster management system in the Village/SubDistrict are then realized in the form of legislation, planning, institutional, and financing as well as capacity building. Historically, the disaster-resilient village program started from a disaster-idle village that was in 2011-2012 administered by the health service. Meanwhile, in 2013 management was under the social service. In 2012, it set by Perka BNPB No. 1 in 2012 become village disaster resilient facilitated by BPBD?

The Village/Sub-District resilient disaster village has a self-reliant ability to adapt and face disaster threats, and recover immediately from adverse catastrophe impacts, if affected by disasters. Thus, disaster resilient of Village/Sub-District has the ability to recognize threats in its territory and is able to organize Community resources to reduce vulnerability and increase capacity to reduce disaster risk. This capability is embodied in development planning which contains prevention efforts, preparedness, disaster risk reduction and capacity building for post-emergency recovery.

Disaster Resilient of Village/Sub-District Development is one of community-based disaster risk of reduction efforts. Community-based disaster risk reduction is all kinds of efforts to reduce community hazard and vulnerability, and increase the preparedness capacity, which planned and implemented by the public as the main perpetrator. In the village/sub district of Village Disaster Resilient, communities are actively involved in reviewing, analyzing, addressing, monitoring, evaluating and mitigating catastrophic risks in their region, especially by utilizing local resources to ensure continuity.

(Pemerintah Republik Indonesia, 2007) article 4 describes the disaster management aims to provide protection to the public from disaster threats. Further regulation of the head of BNPB No. 3 in 2008 on guidelines for forming regional disaster Management Agency, stipulates that local governments are responsible for protecting communities from threats and the impacts of providing information and disaster Knowledge of hazard and disaster risk in the region. Prevention execute through education, training and improvement of skills in the implementation of disaster management and social protection as well as provision of security, especially for disaster vulnerable groups. 
Village/ Sub-District Disaster Resilient are one of the embodiments of the Government's responsibility to provide protection to the public from catastrophic threats. The Program is also in line with the strategies that are a priority in the period 2010-2014 such as Disaster Management National Plan, among others, community-based disaster management, increased role of NGOs and government collaborate organizations, and risk reduction program complaints into the development plan. Village/ Sub-District Disaster Resilient also contain aspects of the Community risk reduction initiative to be in the process of regional development. The objectives in the development of Village/ SubDistrict Disaster Resilient are as follows:

1. Protecting communities living in areas prone to danger from catastrophic impacts;

2. Improving community participation, especially vulnerable groups, in the management of resources in order to reduce disaster risk;

3. Improving the institutional capacity of the Community in the management resources and local wisdom maintenance for disaster risk reduction;

4. Increasing Government capacity in providing resource and technical support for disaster risk reduction;

5. Improving cooperation between stakeholders in $\mathrm{PRB}$, local governments, private sector, colleges, NGOs, community organizations and other concerned groups;

\section{a. Planning}

The central government and local governments are responsible for disaster management. Village/ Sub-District Disaster Resilient development catastrophe is in fact part of the implementation of this responsibility that the arrangement is handed over to Village/ Sub-District Disaster Resilient, and is the responsibility of the village government or sub-district. Governments and local governments will facilitate this program by providing resources and technical assistance required by Villages/ SubDistrict. The development of Village/ Sub-District Disaster Resilient must be covered by the Village development Plan, both in the village medium term development plan and village government work plan.

The mechanism of planning and budgeting Village/ Sub-District Disaster Resilient program discussed through the Village Development Planning Deliberation Forum known as (Musrenbangdes). While the activities in the framework of the development Village/ Sub-District Disaster Resilient is proposed through the city development planning deliberation. At the village implementation level, the development of Village/ Sub-District Disaster Resilient must be based on a minimum of village head regulation, which should not contradict the legislation on it. At the administrative level of the village, the development of Village/ Sub-District Disaster Resilient refers to the policies or regulations established by the mayor.

\section{b. Institutional}

The Disaster Management Forum known as (FRB) at the village level, has been established in 2015 and has had formal legality as an official institution. This Forum was formed aims to educate and socialize the danger of disaster since standing until now there have been 200 people who are trained for disaster preparation in Pasawahan Village that are related to Merapi Mount disaster, forest fire, flood, avalanche and epidemic of other diseases.

The similar institutional is formed in the village of Rancabango, involving multi sectors of the village government devices and the regional disaster management agency that made an agreement with the duty legality to organize the training to community members consisting of women groups, PKK, RT/ RW, community leaders, youth organizations and coral Cadets. Meanwhile, in Karyamekar Village, it is formed the institutional disaster in 2016, until now there are already 200 communities involved. It consists of village officials, RT/RW, cadres of PKK, community leaders and youth figures. Information dissemination is important in training as a preliminary approach in providing knowledge related to the community at the time of the Village Forum, discussion forum, studies and other discussion forums.

\section{c. Capacity Development}

Capacity building Program in Pasawahan Village is characterized by the training to DisasterResilient Villages known as Destana volunteers and village devices about the disaster that was given by the BPBD in Garut District in the form of socialization, catastrophic identification, contingency, evacuation route through the maps of disaster. In addition, volunteers are guided by the countermeasures. As for in Rancabango Village communities did not get direct training from the Regional Disaster Management Agency known as (BPBD) but only those involved in full is Destana volunteers. The participation in the village is very high, seen from the post-disaster flood work that occurred in 2017 and the involvement of women in Rancabango Village as a cadre of PKK that was seen as a volunteer Destana post flood. 
While strengthening the capacity in Karyamekar Village with the role of volunteers in conveying information from Meteorology, Climatology, and Geophysical Agency known as BMKG and the continued to be forwarded to citizens with evacuation pathways made by the community. Through a boot camp forum and monthly meetings, the capacity development is given to villagers both formally and informally.

\section{CONCLUSION}

Disaster management that compiled by Regional Disaster Management Agency (BPBD) as an official organization that organizes community resources in four villages in Garut District needs to be appreciated. Initiating the formation of disaster Management Forum (FRB) in disaster resilient village is as the first step in developing effective countermeasures planning. Disaster-Resilient Villages known as Destana can be considered to increase the participation of citizens to the sensitivity and concern for the flood disaster that often occurs in Garut District.

Through three approaches, namely planning, institutional and strengthening capacity in DisasterResilient Villages known as Destana society has a high social sense and concern for society. The contemplation carried out in the village has shown that institutional and strengthening capacity is important. However, it is still limited to the limited management of volunteer resources because BPBD conducts training according to technical guidelines. Therefore, the role under Destana volunteers continued the informal to the public in general would be catastrophic hazards.

The presence of Disaster-Resilient Villages known as Destana surely is an advantage for citizens it is not optimal. It needs serious and integrated efforts between institutions and the availability of budgets in the training and countermeasures of disaster response so Destana has toughness and community in all circles willing and always vigilant in the face of disaster. In addition to disaster response training activities, Destana also encourages citizens to care about the surrounding environment by fond of planting trees and other reforestation activities; it also affects natural sustainability and shelter Community.

\section{REFERENCES}

Anam, A. K., Andarini, S., R.P, K., Rismawan, Okta, Damayanti, D., ... Dewi, T. (2016). Kesiapsiagaan masyarakat Afdeling Gunung Pasang dalam menghadapi bencana banjir bandang. Jurnal Ilmu Kesehatan. 5, (2), 1-8. https://doi.org/10.32831/jik.v5i2.143

Arifa, F. N. (2018). Mitigasi Bencana Pada Sektor Pendidikan Formal. Info Singkat.

Fisher, A. (1991). Risk Communication Challenges. Risk Analysis. 11, (2), 173-179 https://doi. org/10.1111/j.1539-6924.1991.tb00590.x

Government Regulation Number 21 in 2008 about Disaster Management

Harahap, S. R. (2016). Analisis Penutupan Lahan, Laju Erosi Aktual dan Tolerable Soil Loss di Sub DAS Tapung Kanan. In Seminar Nasional "Pelestarian Lingkungan \& Mitigasi Bencana."

Harliani, F. (2014). Persepsi Masyarakat Kampung Cieunteung, Kabupaten Bandung tentang Rencana Relokasi Akibat Bencana Banjir. Jurnal Perencanaan Wilayah Dan Kota. 25, (1), 37-57. https://doi.org/10.5614/ jpwk.2014.25.1.3

h t t p s : //garutkab.bps.go.id/ statictable/2016/12/08/125/luas-wilayahmenurut-kecamatan-di-kabupatengarut-2015.html

Larsson, G., \& Enander, A. (1997). Preparing for disaster: public attitudes and actions. Disaster Prevention and Management: An International Journal. 6, (1), 11-21. https:// doi.org/10.1108/09653569710162415

Otway, H., \& von Winterfeldt, D. (1992). Expert Judgment in Risk Analysis and Management: Process, Context, and Pitfalls. Risk Analysis. 12, (1), 83-93. https://doi. org/10.1111/j.1539-6924.1992.tb01310.x

Pancasilawan, et. al. (2020). Mitigation of Disaster Risk Reduction in Pangandaran Regency. Sosiohumaniora. 22, (2). 214-212. https://doi. org/10.24198/sosiohumaniora.v22i2.25774

Pemerintah Republik Indonesia. (2007). UndangUndang Nomor 24 Tahun 2007 tentang Penanggulangan Bencana. Pemerintah Republik Indonesia.

Perry, R. W., \& Lindell, M. K. (1997). Principles for managing community relocation as a hazard mitigation measure. Journal of Contingencies and Crisis Management. 5, (1), 49-59 https:// doi.org/10.1111/1468-5973.00036

Presidential Regulation Number 8 in 2008 about National Disaster Management Agency 
Ramli, S. (2010). Pedoman Praktis Manajemen Resiko dalam Perspektif K3. dian rakyat.

Regulation of Ministry of Home Affairs Number 46 in 2008 about the Organizational Guidelines and the Regional Disaster Management Agency

Regulation of the Head of National Disaster Management Agency No. 3 in 2008 on Guidelines in Forming Regional Disaster Management Agency
Regulation of the Head of the National Disaster Management Agency No. 11 in 2008 on Post Disaster Rehabilitation and Reconstruction Guidelines.

Weisæth, L. (1989). A study of behavioural response to an industrial disaster. Acta Psychiatrica Scandinavica. 80, (s355), 13-24. https://doi. org/10.1111/j.1600-0447.1989.tb05250.x 